\title{
Traditional Knowledge and Formulations of Medicinal Plants Used by the Traditional Medical Practitioners of Bangladesh to Treat Schizophrenia Like Psychosis
}

\author{
Md. Nasir Ahmed and Md. Nur Kabidul Azam \\ Ethnobotany \& Ethnomedicine Division, TechB Herbal Solution, Bheramara, Kushtia 7040, Bangladesh \\ Correspondence should be addressed to Md. Nasir Ahmed; nasir.ahmedbd@hotmail.com
}

Received 19 March 2014; Revised 28 May 2014; Accepted 30 May 2014; Published 30 June 2014

Academic Editor: Jouko Miettunen

Copyright ( 2014 Md. N. Ahmed and Md. N. Kabidul Azam. This is an open access article distributed under the Creative Commons Attribution License, which permits unrestricted use, distribution, and reproduction in any medium, provided the original work is properly cited.

\begin{abstract}
Schizophrenia is a subtle disorder of brain development and plasticity; it affects the most basic human processes of perception, emotion, and judgment. In Bangladesh the traditional medical practitioners of rural and remote areas characterized the schizophrenia as an insanity or a mental problem due to possession by ghosts or evil spirits and they have used various plant species' to treat such symptoms. The aim of the present study was to conduct an ethnomedicinal plant survey and documentation of the formulations of different plant parts used by the traditional medical practitioners of Rangamati district of Bangladesh for the treatment of schizophrenia like psychosis. It was observed that the traditional medical practitioners used a total of 15 plant species to make 14 formulations. The plants were divided into 13 families, used for treatment of schizophrenia and accompanying symptoms like hallucination, depression, oversleeping or insomnia, deterioration of personal hygiene, forgetfulness, and fear due to evil spirits like genies or ghost. A search of the relevant scientific literatures showed that a number of plants used by the medicinal practitioners have been scientifically validated in their uses and traditional medicinal knowledge has been a means towards the discovery of many modern medicines. Moreover, the antipsychotic drug reserpine, isolated from the dried root of Rauvolfia serpentina species, revolutionized the treatment of schizophrenia. So it is very much possible that formulations of the practitioner, when examined scientifically in their entireties, can form discovery of lead compounds which can be used as safe and effective antipsychotic drug to treat schizophrenia.
\end{abstract}

\section{Introduction}

Schizophrenia is a psychological disorder characterized by psychotic symptoms: hallucinations and delusions that significantly affect emotions, behavior, and, most notably, mental processes and mental contents. Psychosis is a condition of mental illness that causes a person to lose his or her sense of reality. Schizophrenia is a type of psychosis meaning spilt mind which often describes as a mental disorder characterized by impairments in the perception or expression of reality and by significant social or occupational dysfunction. People with this disease have delusions, hallucinations, disorganized speech, grossly disorganized behavior, or catatonic behavior $[1,2]$. The world over, from China or Finland to the United States or New Guinea, approximately $1 \%$ of the population will develop schizophrenia at some point in their lives [3,4]. Schizophrenia is one of the top five causes of disability among adults in developed nations, ranking with heart disease, arthritis, drug use, and HIV [5]. In the United States, about $5 \%$ of people with schizophrenia (about 100,000 individuals) are homeless, $5 \%$ are in hospitals, and $6 \%$ are in jail or prison [6]. Together, these three groups of people represent about $16 \%$ of Americans with schizophrenia; in contrast, $34 \%$ of people with this disorder live independently. According to World Health Organization (WHO) at least 40 million people in the world suffer from mental disorders such as schizophrenia and dementia [7]. Over 10\% of schizophrenia patients ultimately commit suicide $[8,9]$; this makes the disease a serious psychiatric illness among the various nationalities of the world. 
Bangladesh is a densely populated area where prevalence of psychiatric illness is not less than that of any other country in the world. A study showed that $29 \%$ of patients attending general practice were suffering from functional disorder and $6 \%$ from both functional and organic disorders. The same study demonstrated that $47 \%$ of patients were suffering from neurotic disorder, $37 \%$ from psychosomatic disorder, $10 \%$ from affective disorder, $1.44 \%$ from schizophrenia, $2.88 \%$ from substance use disorder, and $2 \%$ from organic psychiatric syndrome [10]. Another study conducted in Outpatient Department of National Institute of Mental Health (NIMH), Dhaka, Bangladesh, revealed that $37.4 \%$ of patients were suffering from schizophrenia and schizophrenia like psychotic disorders, $16.14 \%$ from anxiety disorders, $11.19 \%$ from major depressive disorder, and $8.95 \%$ from bipolar mood disorder [11]. In the Dhaka city, most of the patients $(70.4 \%)$ were from urban background and from rural area $29.6 \%$ patients [12]. According to other studies it was seen that across various countries, schizophrenia is more common among people in urban areas and lower socioeconomic classes than among people in rural areas and higher socioeconomic classes [13, 14].

Antipsychotic agents are the cornerstone of acute and maintenance treatment of schizophrenia and are effective in the treatment of hallucinations, delusions, and thought disorders, regardless of etiology. In recent decades, the modern psychiatry has introduced herbal medicine in the treatment of psychiatric disorders including schizophrenia. After the rise of a pharmaceutical industry in the last century and significant progress in the treatment, a period of disappointment comes in accepting the fact that synthetic drugs are not almighty. Due to this fact, there has been a growing interest in the last decades for the treatment of psychiatric disorders including schizophrenia by using alternative and complementary methods [15] and a study revealed that $44 \%$ of psychiatric patients with schizophrenia (9\%) had used herbal medicine (mainly for psychiatric purposes) during the previous 12 months [16].

Plants contain various phytochemicals and these phytochemicals can play an important role in reducing occurrences of many diseases by boosting up various organ functions of the human body. Many traditional healing herbs and their parts have been shown to have medicinal value and can be used to prevent, alleviate, or cure several human diseases [17]. It has also been observed that number of modern drugs has been derived from plants used by the indigenous people [18]. Modern drugs like aspirin, atropine, ephedrine, digoxin, morphine, quinine, reserpine, and tubocurarine are examples, which were originally discovered through observations of traditional cure methods of indigenous peoples [19]. Presently, there is a resurgence of herbal medicine as people want more control in their personal healthcare. The U.S. herbal market is growing tremendously with consumer demand way ahead of regulatory agencies. It is interesting to note that four (Ginkgo, St. John's Wort, Valerian, and Kava) of the top ten herbs purchased in the U.S. (according to 1999 Whole Foods Survey) have psychotropic activity. Recent trends in research into African plant uses show that traditional medicine is commonly used to treat neurological disorders in the West African region, and some recent publications are available [20].

In Bangladesh, traditional medical practice is still ongoing. The traditional medical practitioners (generally known as Kabirajes by the mainstream community) perform a central role in providing primary healthcare to the rural inhabitants of Bangladesh. There are 86,000 villages in the country and almost every village has one or two traditional Kabirajes. They are the providers of primary healthcare to village populations of Bangladesh and moreover they are the important sources of ethnomedicinal knowledge. The practices of the Kabirajes extend throughout both urban and rural areas of the country, although rural practice is more extensive than urban practice.

The advantage of the Kabirajes is that they rely chiefly on medicinal plants for treatment. The formulations are rarely complex and usually consist of simple extraction of juice of whole plant or plant part through squeezing plant part. The juice is then administered orally or typically applied depending on the nature of diseases. The previous ethnomedicobotanical studies conducted among folk and tribal medicinal practitioners of the country have noticed considerable variation between the medicinal plants selected by different Kabirajes for treatment of a given ailment [21-25]. The aim of the present study was to document the traditional medicine knowledge as well formulations of medicinal plants used by the traditional medical practitioners of Rangamati district in the Chittagong Hill Tracts (CHT) region of Bangladesh for the treatment of schizophrenia like psychosis.

\section{Materials and Methods}

2.1. Study Area. For the present study, survey was done between March to Mid-April' 2013, in the largest district of the country called Rangamati which is located in the CHT region. It is consists of 10 upazilas and bordered by the Tripura state of India to the north and Bandarban district to the south. The area of the district is $6116 \mathrm{~km}^{2}$ of which $1292 \mathrm{~km}^{2}$ is riverine and $4825 \mathrm{~km}^{2}$ is under forest vegetation. The main survey was conducted in the Rangamati Sadar Upazila (located at $22.6500^{\circ} \mathrm{N} 92.1833^{\circ} \mathrm{E}$ ), which consists of 6 unions, on the information about medicinal plants commonly used for treatment of psychotic disorders with particular attention to schizophrenia. The study area for this specific ethnomedicinal survey was selected by the authors themselves regarding information on the noted traditional medical practices. Moreover, the study area as well as the total CHT region is very rich in species diversity. We are conducting systematic ethnomedicinal survey of Bangladesh since 2011 as to explore how do the Kabirajes of Bangladesh select medicinal plants for treatment of any ailment. In order to address such question we conducted this specific survey among Kabirajes of Rangamati Sadar Upazila of Bangladesh (Figure 1). The above question is more important from the viewpoint that how and why medicinal plants are selected by the TMPs can lead the way towards a better linking between traditional knowledge with biomedical science [26, 27].

2.2. Mode of Interview and Plant Data Collection. The collection of data through interviews of 3 traditional medical 


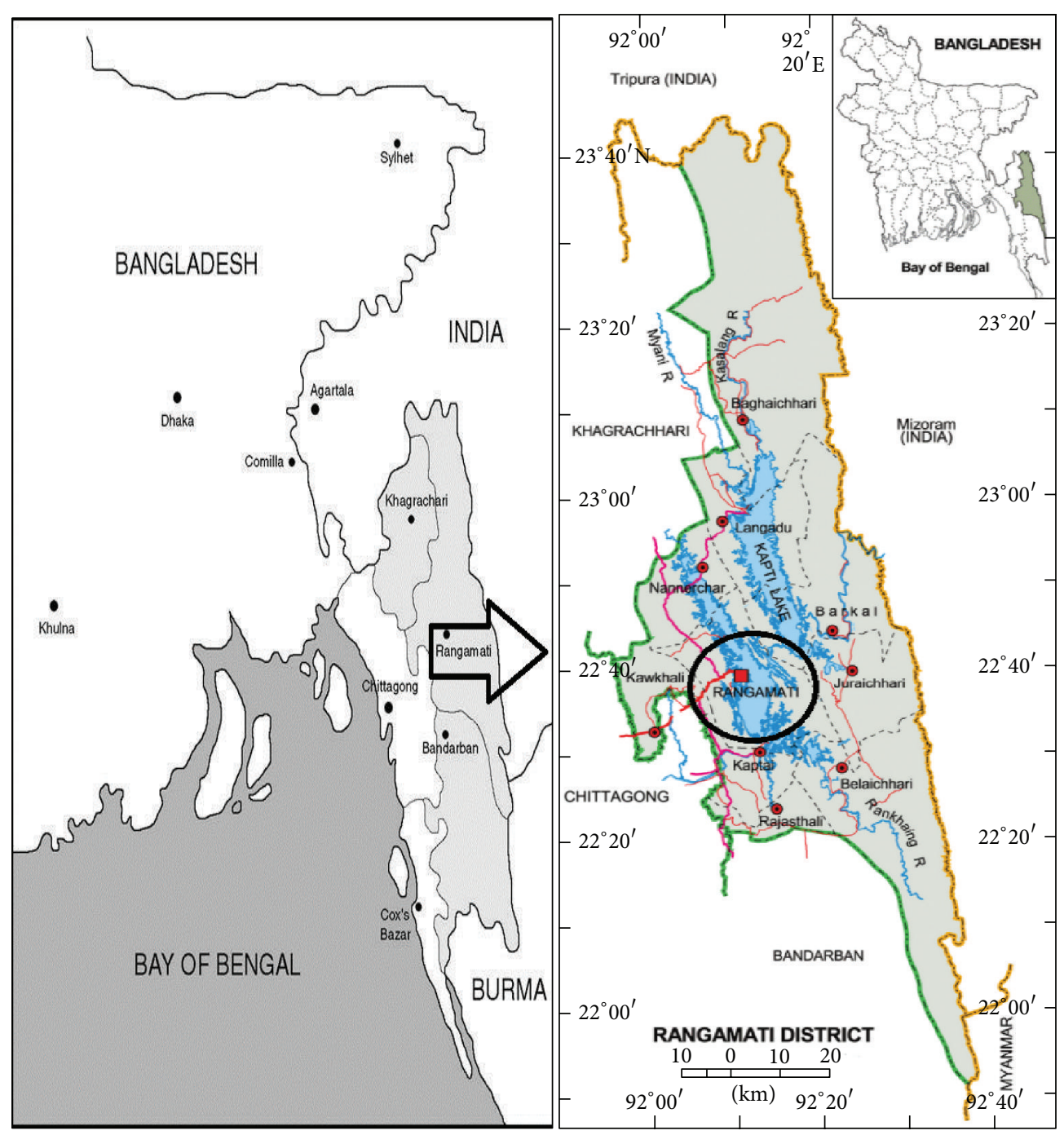

(a)

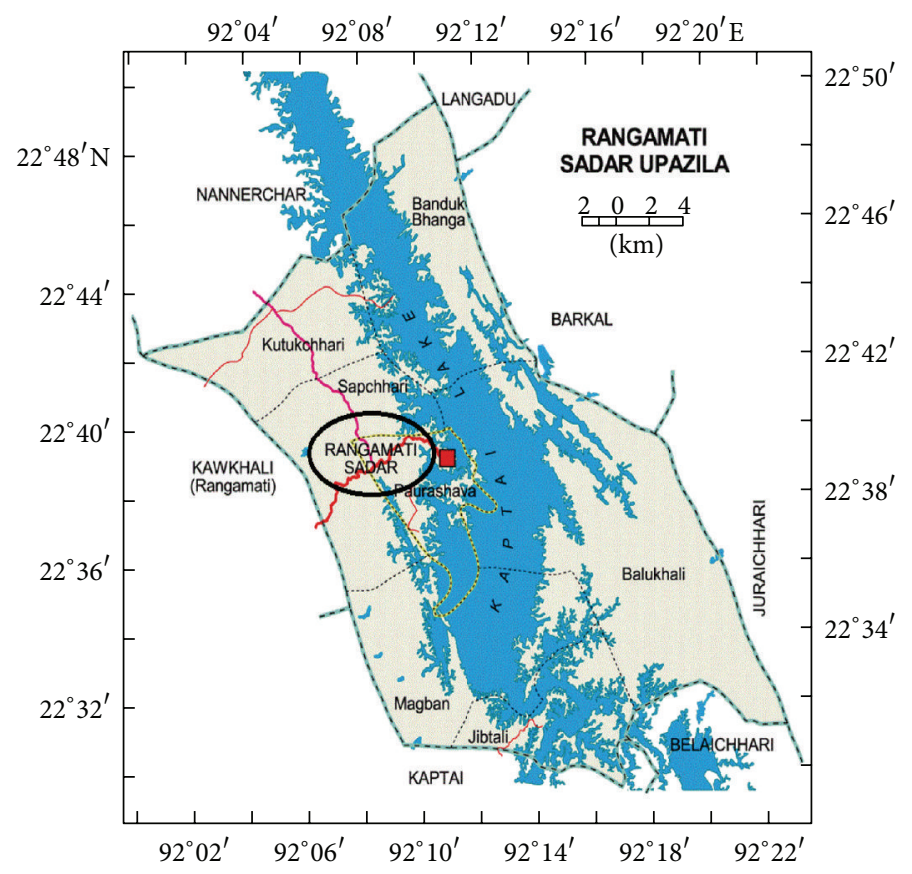

(b)

FIGURE 1: Map of Bangladesh showing the Rangamati district. Study site is marked on the map with black round shade. 
practitioners (TMP; aged between 61-67) was conducted by the researchers themselves with the help of a semistructured questionnaire. The number of 3 TMPs was chosen on the basis of recommendation of the local inhabitants as to being more proficient and reputed to their practices. In the preliminary survey, the TMPs were specifically asked as to whether they know and treat schizophrenia, the basis for their diagnosis, and their mode of treatment when the disease has been diagnosed as schizophrenia. According to folk medical practitioners, the symptoms were hallucinations, over sleeping in the day, insomnia, staying alone in the dark room, anxiety, being silent or not so much interested to keep attached with family members, and most commonly getting fear due to invisible person (as per patient's thoughts). The traditional medical practitioners defined this fear to be due to evil spirits, genies, or ghosts. The basic method followed was one of guided fieldwork [28-30]. Information collected from the Kabirajes consisted of medicinal plants or plant parts used, formulations, and dosage. The information was noted down during the daytime interviews. At the end of each interview plant specimens shown by the traditional medical practitioners were collected, dried, and later brought back to the Dhaka for identification at the Bangladesh National Herbarium and all the voucher specimens were deposited there. Nomenclature of plants was compiled from the plant list database [31]. For this specific ethnomedicinal survey, the number of visits was made to the traditional medical practitioners to gain their confidence.

\section{Results}

It was observed that the 3 traditional medical practitioners (TMP) of the Rangamati district used a total of 14 formulations from the 15 plant species, distributed into 13 families for treatment of schizophrenia like psychotic episodes. The Rubiaceae and Lamiaceae families were contributing 2 plants, the rest of the plant families contributed one plant each. The various plant parts were used including leaf, roots, bark, stem, flower, seed, and fruit. This study recorded that several parts or individual plant species are used as medicine. Leaves constituted the major plant part used, forming $47.62 \%$ of total uses. Barks and seeds each constituted $14.28 \%$ of total uses. The other plant parts mentioned constituted, respectively, $9.52,4.76,4.76$, and $4.76 \%$ of total uses (Figure 2).

The medicinal knowledge of TMPs was derived from the earlier generation practitioners, with whom every TMP had to serve a period of apprenticeship and training before they could practice independently. This medicinal knowledge has come out of practice through the centuries and every practitioner had their own lists of plants for treatment of any particular disease or disorder. As mentioned earlier all 3 TMPs were interviewed separately, so the plants advised by the TMPs did not reflect any individual opinion. It can be concluded by the interviewers that schizophrenia and other related psychotic problems have existed for centuries among the people surveyed and various TMPs have developed their own medicinal plant formulations for treatment of schizophrenia like psychosis, possibly through trial and error methods over centuries long practices.

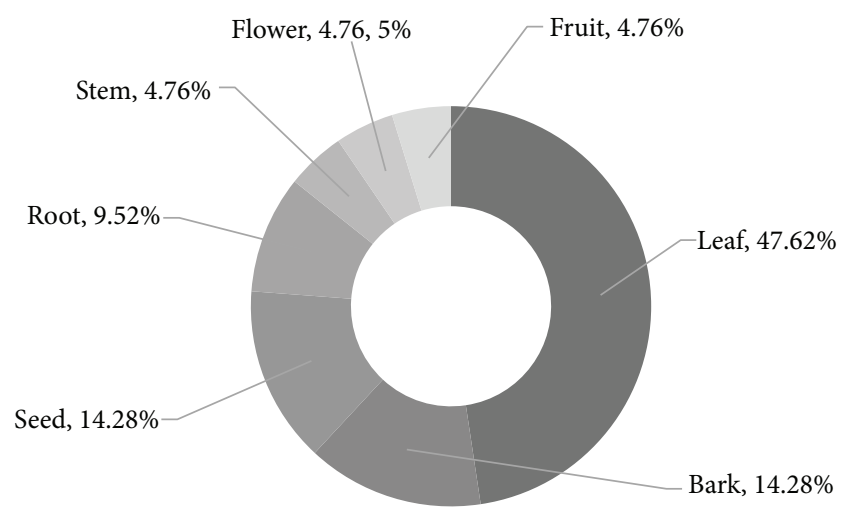

Figure 2: Parts of medicinal plants used by the traditional medical practitioners of Rangamati Sadar Upazila to treat schizophrenia like psychosis.

Any sort of complex formulations was avoided by the TMPs for the treatment of schizophrenia like psychosis. Generally fruits and seeds were consumed directly or with water. In most cases, juice obtained from squeezed plant part was advised to be taken or pills made from paste of plant part taken orally. It was noted that mashed leaves of Piper retrofractum are taken with rice. A combination of bark and seed of Thevetia peruviana paste is taken orally. Another formulation suggested by a TMP was that juice from macerated Euphorbia neriifolia leaves is taken orally; the formulation was also used to keep head cool and to increase memory of a patient as per the TMP. There were also mentioned some more easy formulations: smell of flower of Abroma augusta is taken with the nose and leaves of Vitex negundo were carried alongside the body. If a patient is in severe condition then the leaves of Cannabis sativa were used to make vapor and the vapor is taken by the nose, as advised by a TMP. Leaf juice of Ocimum americanum is mixed with seeds of Brassica juncea and taken orally till cure. Most of the formulations were usually administrated orally with three exceptions. The rest of the formulations were given in Table 1 .

In our present study, TMPs recommended different forms of medication including juice ( 3 species), pill, vegetable and paste ( 2 each), tablet, vapor, oil message, decoction (1 species each), and others (3). Most often standard medicines are prescribed in mixed ingredient form by mixing several valuable medicinal plants or several plant parts of one plant species. TMPs believe that using plant or plant part mixtures in the preparation of medicine is important as a single plant alone may not be sufficient to cure any disease completely and the combination of several medicinal plants increases the quality and efficacy of medicine. Similar observations have also been found in Nepal and India $[32,33]$.

\section{Discussions}

Investigation into the mechanism of action of the drugs used to treat schizophrenia has not provided clear understanding of the pathogenesis of the disease. While schizophrenia 
TABLE 1: Medicinal plants used by the traditional medical practitioners of Rangamati district for treatment of schizophrenia like psychotic episodes.

\begin{tabular}{|c|c|c|c|}
\hline $\begin{array}{l}\text { Serial } \\
\text { number }\end{array}$ & Formulations and dosage & Parts used & $\begin{array}{c}\text { Botanical } \\
\text { name/vernacular name }\end{array}$ \\
\hline 1 & $\begin{array}{l}\text { Leaves of Piper retrofractum (Piperaceae) are } \\
\text { taken orally in mashed form as vegetable with } \\
\text { rice till cure. }\end{array}$ & Leaf & $\begin{array}{l}\text { Piper retrofractum } \\
\text { Vahl/Choi }\end{array}$ \\
\hline 2 & $\begin{array}{l}\text { Juice obtained from macerated leaves or roots } \\
\text { of Ficus hirta (Moraceae) is taken orally till } \\
\text { cure. }\end{array}$ & Leaf, root & Ficus hirta Vahl./Pakur \\
\hline 3 & $\begin{array}{l}\text { A combination of bark and seed of Thevetia } \\
\text { peruviana (Apocynaceae) paste is taken orally } \\
\text { till cure. }\end{array}$ & Bark, seed & $\begin{array}{l}\text { Thevetia peruviana } \\
\text { (Pers.) K. Schum./Holde } \\
\text { Korobi }\end{array}$ \\
\hline 4 & $\begin{array}{l}\text { A combination of leaf and seed paste from } \\
\text { Datura metel L. (Solanaceae) is taken orally or } \\
\text { macerated leaves are pressed to the nose. }\end{array}$ & Leaf, seed & Datura metel L./Dhutura \\
\hline 5 & $\begin{array}{l}\text { Juice from macerated Euphorbia neriifolia } \\
\text { (Euphorbiaceae) leaves is taken orally. }\end{array}$ & Leaf & $\begin{array}{l}\text { Euphorbia neriifolia } \\
\text { L./Monshaseez }\end{array}$ \\
\hline 6 & $\begin{array}{l}\text { Juice is collected from macerated bark of } \\
\text { Randia dumetorum (Rubiaceae). It is then } \\
\text { dried and turned into powder, which is mixed } \\
\text { with sugar. Tablets weighing } 5 \mathrm{~g} \text { each are made } \\
\text { from the mixture and taken till cure }\end{array}$ & Bark & $\begin{array}{l}\text { Randia dumetorum } \\
\text { (Retz.) Lam/Monkata }\end{array}$ \\
\hline 7 & $\begin{array}{l}\text { Aegle marmelos (Rutaceae) leaves and roots } \\
\text { crushed and made into } 1 / 2 \text { tola amount pills. } \\
\text { Pills are taken twice daily for three days. ( } 1 \text { tola } \\
=11.66 \mathrm{~g} \text { ) }\end{array}$ & Leaf, root & $\begin{array}{l}\text { Aegle marmelos (L.) } \\
\quad \text { Corr./Bel }\end{array}$ \\
\hline 8 & $\begin{array}{l}\text { Litsea polyantha (Lauraceae) bark is macerated } \\
\text { with } 1 \mathrm{~g} \text { sugar to obtain juice, which is then } \\
\text { taken orally. }\end{array}$ & Bark & $\begin{array}{l}\text { Litsea polyantha } \\
\text { Juss./Uruijja, Menda }\end{array}$ \\
\hline 9 & $\begin{array}{l}\text { Leaves of Coccinia grandis (Cucurbitaceae) are } \\
\text { boiled and the decoction is taken orally. }\end{array}$ & Leaf & $\begin{array}{l}\text { Coccinia grandis (L.) J. } \\
\text { Voigt/Telakuchi }\end{array}$ \\
\hline 10 & $\begin{array}{l}\text { Leaf juice of Ocimum americanum (Lamiaceae) } \\
\text { are mixed with mashed seeds of Brassica juncea } \\
\text { (Cruciferae) and taken orally till cure. }\end{array}$ & Leaf, seed & $\begin{array}{l}\text { Ocimum americanum } \\
\text { L./Radha tulshi } \\
\text { Brassica juncea (L.) } \\
\text { Czern./Shorisha } \\
\end{array}$ \\
\hline 11 & $\begin{array}{l}\text { Smell of flower of Abroma augusta (Malvaceae) } \\
\text { is taken with the nose or crushed stems are } \\
\text { taken with Aloe vera and sugar twice daily for } \\
\text { seven days till cure. }\end{array}$ & Flower, steam & $\begin{array}{l}\text { Abroma augusta } \\
\text { L.f./Ulot Kombol }\end{array}$ \\
\hline 12 & $\begin{array}{l}\text { Leaves of Vitex negundo (Lamiaceae) are kept } \\
\text { or carried alongside the body. Another } \\
\text { formulation is to take pills in the morning } \\
\text { made from the leaves. }\end{array}$ & Leaf & $\begin{array}{l}\text { Vitex negundo } \\
\text { L./Nishinda }\end{array}$ \\
\hline 13 & $\begin{array}{l}\text { Leaves from Cannabis Sativa (Cannabaceae) } \\
\text { are used to make oil then message on the scalp } \\
\text { till cure. If a patient is in severe condition then } \\
\text { the leaves were used to make vapor and the } \\
\text { vapor is taken by the nose. }\end{array}$ & Leaf & $\begin{array}{l}\text { Cannabis Sativa } \\
\text { L./Bhang, Siddhi }\end{array}$ \\
\hline 14 & $\begin{array}{l}\text { Ripe fruit of Morinda citrifolia (Rubiaceae) is } \\
\text { eaten as raw and mashed leaves were eaten as } \\
\text { vegetable. }\end{array}$ & Fruit, leaf & $\begin{array}{l}\text { Morinda citrifolia } \\
\text { Linn./Holdi Kachu, Noni }\end{array}$ \\
\hline
\end{tabular}

is highly heritable, the genetics are complex and the interpretation of genetic data has proven difficult. Now advances in phenotypic analysis, neuroimaging, genetics, and molecular pathology provide the basis for optimism [34]. Schizophrenia can be understood as a subtle disorder of brain development [35-37].
4.1. Neural Communication in Schizophrenia. Recent findings have shown changes in markers in a number of neurotransmitter systems in the brains of subjects with schizophrenia which include the dopaminergic, serotonergic, glutamatergic, and GABAergic systems of the CNS. Many of these changes also appear to be regionally specific, and abnormalities in 
nonneurotransmitter specific pathways have been found in schizophrenia [38]. A major component of the studies used postmortem CNS tissue because these sites are amenable to manipulation by therapeutic agents, in many cases they are the sites of action of drugs which provide antipsychotic activity [39]. Ultimately neurobiology of schizophrenia may help illuminate the nature of normal thought, perception and emotion.

The findings that antipsychotic drugs are dopamine D2 receptor antagonists and the dopamine hypothesis propose that an overproduction of dopamine or an increase in the number or sensitivity of dopamine receptors is responsible for schizophrenia. According to this hypothesis, the excess dopamine or extra sensitivity to this neurotransmitter triggers a flood of unrelated thoughts, feelings, and perceptions. Delusions are then attempt to organize these disconnected events into a coherent, understandable experience [40, 41].

There has been an increasing acceptance that antipsychotic drugs that bind to both the dopamine $\mathrm{D}_{2}$-like receptor family and the serotonin $(5 \mathrm{HT})_{2 \mathrm{~A}}$ receptor have been improved clinical outcomes [42]. Using DNA from peripheral tissue, a number of studies have suggested that mutations in the gene for the $5 \mathrm{HT}_{2 \mathrm{~A}}$ receptor are associated with schizophrenia [43].

The hypothesis that changed glutamatergic function is involved in the pathology of schizophrenia and a glutamate receptor ion channel blocker reduce or exacerbate a schizophrenia like psychosis [44]. The N-methyl-D-aspartate (NMDA) glutamate receptor has been shown to play a crucial role in learning and memory, and hence abnormalities in its functioning may explain some of the deficits associated with schizophrenia, such as deficits in working memory. Studies have found unusually high levels of glutamate in people with schizophrenia, particularly in the frontal lobe $[45,46]$; such an excess of glutamate may disrupt the timing of neural activation in the frontal lobe, which in turn may impair cognitive activities that depend on the smooth coordination of different operations, such as working memory, where information must be actively retained in short-term memory as it is operated upon [47].

Research findings suggest that stress can contribute to schizophrenia because stress affects cortisol production, which in turn affects the brain. The relationship with cortisol appears even in childhood. Children who are at risk for schizophrenia react more strongly to stress, and their baseline levels of cortisol are higher than those of other children [48]. The relationship between stress, cortisol, and symptoms of schizophrenia has also been noted during adolescence [49]. Even after adolescence, people with schizophrenia have higher levels of stress-related hormones, including cortisol [50].

Several lines of evidence implicated the GABAergic system in the pathology of schizophrenia. The study of mRNA encoding the different subunits has now extended original findings on radioligand binding to show an increase in levels of mRNA encoding the $\alpha-1$ subunit of the $\mathrm{GABA}_{\mathrm{A}}$ receptor in Brodmann's areas 9 and 10 from subjects with schizophrenia [51]. There are changes in expression of $\mathrm{GABA}_{\mathrm{A}}$ receptor subunit in schizophrenia which are the finding that there is a marked decrease in levels of mRNA encoding for the short form of the $\gamma 2$ subunit of the $\mathrm{GABA}_{\mathrm{A}}$ receptor in the prefrontal cortex from schizophrenia [52].

\subsection{Herbal Medications in the Enhancement of Brain Function.} Humans consume a wide range of foods, drugs, and dietary supplements that are derived from plants and which modify the functioning of the central nervous system (CNS). The psychoactive properties of these substances are attributable to the presence of plant secondary metabolites; in many cases, the effects of these phytochemicals on the human CNS might be linked either to their ecological roles in the life of the plant or to molecular and biochemical similarities in the biology of plants and higher animals [53]. Schizophrenia as well as other psychotic disorders is likely to involve a complex interplay of many brain systems and neurotransmitters including dopamine, serotonin, and glutamate, and there is extensive evidence that schizophrenia is a biological disease of the brain. The primary mechanism of action involves modulation of neuronal communication, via specific plant metabolites binding to neurotransmitter/neuromodulator receptors [54] and via alteration of neurotransmitter synthesis and general function [55]. Other mechanisms involve stimulating or sedating CNS activity and regulating or supporting the healthy function of endocrine system $[56,57]$. Traditional antipsychotics have been the first step in treating schizophrenia, that is, thorazine (chlorpromazine) is dopamine antagonist, which effectively blocks the action of dopamine and diminishes positive symptoms in approximately $75-80 \%$ of people with schizophrenia who take such antipsychotic medication [58]. Traditional antipsychotics have sedative properties which affect patients quickly; such sedation and improvement in psychotic symptoms can take anywhere from 5 days to 6 weeks [59].

A huge scientific literature focusing on psychoactive herbal extracts and their phytochemicals, encompassing hundreds of thousands of scientific papers, has emerged over recent decades. The vast majority of these papers describe in vitro investigations of the potential mechanisms of action of putatively psychoactive phytochemicals, whereas a much smaller proportion explores their effects in vivo on animals and only a tiny minority investigates their efficacy in humans. Zhang [60] identified extracts and constituents from 85 individual medicinal plants that have demonstrated potential efficacy for treating psychiatric disorders on the basis of animal behavioral models alone.

A study indicated antipsychotic activity along with antianxiety and anticonvulsant from the hydroalcoholic extract of Euphorbia neriifolia leaves in mice and rats [61]. The observation of another study indicated that the anticataleptic activity exhibited by ethanolic extract of Randia dumetorum Lam fruits does not possess antidopaminergic and antiserotonergic activity. Catalepsy usually associated with catatonic schizophrenia [62].

Methanolic extract of Aegle marmelos leaves possessed potential anxiolytic and antidepressant activities in albino mice and also may be served as a potential resource for natural psychotherapeutic agent [63]. In India, Aegle marmelos 
highly reputed ayurvedic medicinal tree and has been used in nervous disorder and as tonic for brain [64, 65]. A survey study conducted by Rahmatullah et al. $[66,67]$ reported that TMP of Santals tribe in Bangladesh used Coccinia grandis for the treatment of mental disorder.

Ocimum americanum possessed relaxant effects [68] and can be considered as beneficial to patients with mental disorders. The seed of Brassica juncea and leaves juice of Ocimum americanum were mixed with leaves of Acorus calamus L. (Acoraceae) for treating mental disorders as well being possessed with evil spirits; such combined formulation was used by the TMP of the Tonchongya tribe of Bangladesh, and whether such beings exist or not is scientifically debatable, any possession by "evil spirits" can be considered as a sort of mental disorder with the status of the patient being in a state of delirium [69]. A. calamus is also used to make brahmyadiyoga (an Ayurvedic medicine system) and has been used for the treatment of schizophrenia. An important general issue is the cost of treatment, as Ayurvedic treatments are cheaper and therefore more accessible to poor people than chlorpromazine, let alone the more recent atypical antipsychotics [70, 71].

The effect of acetone soluble fraction of methanolic extract of roots of the Vitex negundo (50 and $100 \mathrm{mg} / \mathrm{kg}$, i.p.) was studied on haloperidol-induced catalepsy in mice, amphetamine induced stereotyped behaviour in rats, and dopamine-induced contraction isolated vas deferens preparation of rat. The acetone soluble fraction of methanolic extract of isolated of $V$. negundo significantly potentiated haloperidol induced catalepsy, antagonized dose dependent amphetamine-induced stereotyped behaviour, and also antagonized dopamine induced contractions of rat vas deference. The result suggests that the methanolic extract of Vitex negundo possessed antidopaminergic principle [72]. Another study results in mice indicated that roots of Vitex negundo have an effective anxiolytic agent [73].

Since the discovery of the endocannabinoid system, a growing body of psychiatric research has emerged focusing on the role of this system in major psychiatric disorders like schizophrenia, bipolar disorder, major depression, and anxiety disorder. A compound found in Cannabis sativa can treat schizophrenia as effectively as antipsychotic medications, with far fewer side effects, according to a preliminary clinical trial. Researchers led by Markus Leweke of the University of Cologne in Germany studied 39 people with schizophrenia who were hospitalized for a psychotic episode. Nineteen patients were treated with amisulpride, an antipsychotic medication that is not approved in the U.S. but is comparable to other medications that are antipsychotic. The rest of the patients were given cannabidiol (CBD), a substance found in $C$. sativa that is thought to be responsible for some of its mellowing or anxiety-reducing effects [74]. Unlike the main ingredient in marijuana, THC, which can produce psychotic reactions and may worsen schizophrenia, CBD has antipsychotic effects, according to previous research in both animals and humans. The use of CBD for schizophrenia is becoming more and more common. Studies from around the world are showing great promise [75]. Moreover, fMRI results strongly suggest that the antipsychotic effects of $\mathrm{CBD}$ involve the striatum and temporal cortex that have been traditionally associated with psychosis [76].

Antipsychotic-like activity of Morinda citrifolia in mice demonstrated the antidopaminergic effect, suggesting that this plant has antipsychotic-like activity which can be utilized in the treatment of psychiatric disorders [77].

No available scientific literature is found regarding antipsychotic effects of six plants which were used by the traditional medical practitioners' of Rangamati Sadar Upazila, Bangladesh, and these six species are A. augusta L.f, L. polyantha Juss., P. retrofractum Vahl., F. hirta Vahl., T. peruviana (Pers.) K. Schum, and Datura metel L. However, it is very much important to conduct proper scientific study for the evaluation of antipsychotic effects of these plants. Bangladesh has a very rich diversity of medicinal plant species which has been used by the traditional healers of several districts for the treatment of different diseases like mental health problems, brain disorders, malaria, cardiovascular disorders, diabetes, tumor, snake bite, and rheumatoid arthritis [78-85]. Thus the body of the existing ethnomedical knowledge has led to great developments in schizophrenia as well as can be the source for the discovery of new antipsychotic drugs.

\section{Conclusions}

The use of psychoactive plants is practically a universal human phenomenon. Except for a few cultures lacking access to psychoactive plants, humans tend to use them routinely. The psychological and behavioral effects of such plants have been long recognized and information about their uses has been passed down through generations. However, with the advent of modern science we are able to better understand the composition of these plants and how they interact with the nervous system.

The available scientific literature strongly suggests that at least some of the plants used by the traditional medical practitioners of Bangladesh may have strong scientific basis for their use in the treatment of schizophrenia like psychotic episodes. This ethnobotanical data provides an interesting basis for further phytotherapeutical research towards discovery of novel and efficacious antipsychotic drugs, especially concerning uncommonly used species (i.e., A. augusta L.f, L. polyantha Juss., P. retrofractum Vahl., F. hirta Vahl., T. peruviana (Pers.) K. Schum, and Datura metel L.). Although some formulations have drawn attention, in depth clinical trials of each one of the plants presented in the table should be conducted which will be a major tool to prove the benefits for a schizophrenia patient as well as to evaluate more scientific researches for discovering the new antipsychotic drugs with giving less side effects.

\section{Conflict of Interests}

The authors declare that there is no conflict of interests regarding the publication of this paper. 


\section{Acknowledgments}

The authors are grateful to Robin S. Rosenberg and Stephen M. Kosslyn, authors of the book of "Abnormal Psychology," for Chapter 12. The book was very helpful in developing the concept in the field of schizophrenia. Thanks are also due to the traditional medical practitioners of Rangamati for their cooperation and help during the ethnomedicinal survey. All authors edited the paper and read and approved the final paper.

\section{References}

[1] S. Hodgins, "Mental disorder, intellectual deficiency, and crime: evidence from a birth cohort," Archives of General Psychiatry, vol. 49, no. 6, pp. 476-483, 1992.

[2] S. Hodgins, S. A. Mednick, P. A. Brennan, F. Schulsinger, and M. Engberg, "Mental disorder and crime: evidence from a Danish birth cohort," Archives of General Psychiatry, vol. 53, no. 6, pp. 489-496, 1996.

[3] I. I. Gottesman, Schizophrenia Genesis: The Origin of Madness, Freeman, New York, NY, USA, 1991.

[4] J. Perälä, J. Suvisaari, S. I. Saarni et al., "Lifetime prevalence of psychotic and bipolar I disorders in a general population," Archives of General Psychiatry, vol. 64, no. 1, pp. 19-28, 2007.

[5] C. J. L. Murray and A. D. Lopez, Eds., The Global Burden of Disease. A Comprehensive Assessment of Mortality and Disability from Diseases, Injuries, and Risk Factors in 1990 and Projected to 2020, Harvard School of Public Health, Cambridge, Mass, USA, 1996.

[6] E. F. Torrey, Surviving Schizophrenia: A Manual for Families, Consumers, and Providers, Quill, New York, NY, USA, 4th edition, 2001.

[7] A. H. M. Firoz, M. E. Karim, M. F. Alam, A. H. M. Rahman, M. N. Zaman, and V. Chandra, "Community based Multicentric Service Oriented Research on mental illness with focus on prevalence, medical care, awareness and attitude towards mental illness in Bangladesh. WHO published data, 2003-2005," Bangladesh Journal of Psychiatry, vol. 20, no. 1, pp. 9-32, 2006.

[8] J. Addington and P. Bumett, "Working with families in the early stages of Psychosis," in Psychological Interventions in Early Psychosis: A Treatment Handbook, J. F. M. Gleeson and P. D. McGorry, Eds., pp. 99-116, John Wiley \& Sons, Chichester, UK, 2004.

[9] Department of Health, The Policy Implementation Guide for Mental Health, Her Majesty's Stationery Office (HMSO), London, UK, 2001.

[10] M. A. Mohit, "Diagnosis of patients attending Out Patient Department (OPD) of NIMH," Bangladesh Journal Psychiatry, vol. 15, no. 1, pp. 5-12, 2001.

[11] M. Gelder, D. Gath, R. Mayou, and P. Cowen, Oxford Text Book of Psychiatry, Oxford University Press, Oxford, UK, 5th edition, 2005.

[12] A. Fahmida, M. A. Wahab, and M. M. Rahman, "Pattern of psychiatric morbidity among the patients admitted in a private psychiatric clinic," Bangladesh Journal of Medical Science, vol. 8, no. 1, pp. 1-2, 2009.

[13] H. Freeman, "Schizophrenia and city residence," British Journal of Psychiatry, vol. 164, no. 23, pp. 39-50, 1994.

[14] P. B. Mortensen, C. B. Pedersen, T. Westergaard et al., "Effects of family history and place and season of birth on the risk of schizophrenia," The New England Journal of Medicine, vol. 340, no. 8, pp. 603-608, 1999.

[15] D. Babić and R. Babić, "Complementary and alternative medicine in the treatment of schizophrenia," Psychiatria Danubina, vol. 21, no. 3, pp. 376-381, 2009.

[16] G. Elkins, M. H. Rajab, and J. Marcus, "Complementary and alternative medicine use by psychiatric inpatients," Psychological Reports, vol. 96, no. 1, pp. 163-166, 2005.

[17] U. Dhar, R. S. Rawal, S. S. Samant, S. Airi, and J. Upreti, "People's participation in Himalayan biodiversity conservation: a practical approach," Current Science, vol. 76, no. 1, pp. 36-40, 1999.

[18] J. M. Balick and P. A. Cox, Plants, People and Culture: the Science of Ethnobotany, Scientific American Library, New York, NY, USA, 1996.

[19] A. H. Gilani and A. U. Rahman, "Trends in ethnopharmacology," Journal of Ethnopharmacology, vol. 100, no. 1-2, pp. 43-49, 2005.

[20] M. M. Romeiras, M. C. Duarte, B. Indjai, and L. Catarino, "Medicinal plants used to treat neurological disorders in West Africa: a case study with Guinea-Bissau Flora," American Journal of Plant Sciences, vol. 3, no. 7, pp. 1028-1036, 2012.

[21] M. A. H. Mollik, M. S. H. Hossan, A. K. Paul, M. TaufiqUr-Rahman, R. Jahan, and M. Rahmatullah, "A comparative analysis of medicinal plants used by folk medicinal healers in three districts of Bangladesh and inquiry as to mode of selection of medicinal plants," Ethnobotany Research and Applications, vol. 8, pp. 195-218, 2010.

[22] M. Rahmatullah, M. A. H. Mollik, M. N. Ahmed et al., "A survey of medicinal plants used by folk medicinal practitioners in two villages of Tangail district, Bangladesh," American-Eurasian Journal of Sustainable Agriculture, vol. 4, no. 3, pp. 357-362, 2010.

[23] M. S. Hossan, A. Hanif, B. Agarwala et al., "Traditional use of medicinal plants in Bangladesh to treat urinary tract infections and sexually transmitted diseases," Ethnobotany Research and Applications, vol. 8, pp. 61-74, 2010.

[24] M. Rahmatullah, D. Ferdausi, M. A. H. Mollik, R. Jahan, M. H. Chowdhury, and W. M. Haque, "A survey of medicinal plants used by Kavirajes of Chalna area, Khulna district, Bangladesh," African Journal of Traditional, Complementary and Alternative Medicines, vol. 7, no. 2, pp. 91-97, 2010.

[25] F. I. Jahan, M. R. U. Hasan, R. Jahan et al., "A comparison of medicinal plant usage by folk medicinal practitioners of two adjoining villages in Lalmonirhat district, Bangladesh," American-Eurasian Journal of Sustainable Agriculture, vol. 5, no. 1, pp. 46-66, 2011.

[26] B. Berlin and E. A. Berlin, "Anthropological issues in medical anthropology," in Ethnobotany and the Search for New Drugs, G. Prance, Ed., Ciba Foundation Symposium No. 185, pp. 240-258, John Wiley and Sons, New York, NY, USA, 1994.

[27] C. H. Browner, B. R. Ortiz de Montellano, and A. J. Rubel, "A methodology for cross-cultural ethnomedical research," Current Anthropology, vol. 29, pp. 681-702, 1988.

[28] G. J. Martin, Ethnobotany: A "People and Plants" Conservation Manual, Chapman and Hall, London, UK, 1995.

[29] M. N. Alexiades, Ed., Selected Guidelines for Ethno Botanical Research: A Field Manual, The New York Botanical Garden, New York, NY, USA, 1996.

[30] P. Maundu, "Methodology for collecting and sharing indigenous knowledge: a case study," Indigenous Knowledge and Development Monitor, vol. 3, pp. 3-5, 1995. 
[31] "The plant list database," http://www.theplantlist.org/.

[32] M. Ayyanar and S. Ignacimuthu, "Traditional knowledge of Kani tribals in Kouthalai of Tirunelveli hills, Tamil Nadu, India," Journal of Ethnopharmacology, vol. 102, no. 2, pp. 246-255, 2005.

[33] S. Bhattarai, R. P. Chaudhary, C. L. Quave, and R. S. L. Taylor, "The use of medicinal plants in the trans-himalayan arid zone of Mustang district, Nepal," Journal of Ethnobiology and Ethnomedicine, vol. 6, article 14, 2010.

[34] C. A. Ross, R. L. Margolis, S. A. J. Reading, M. Pletnikov, and J. T. Coyle, "Neurobiology of Schizophrenia," Neuron, vol. 52, no. 1, pp. 139-153, 2006.

[35] S. E. Arnold, K. Talbot, and C. Hahn, "Neurodevelopment, neuroplasticity, and new genes for schizophrenia," Progress in Brain Research, vol. 147, pp. 319-345, 2005.

[36] P. J. Harrison and D. R. Weinberger, "Schizophrenia genes, gene expression, and neuropathology: on the matter of their convergence," Molecular Psychiatry, vol. 10, no. 1, pp. 40-68, 2005.

[37] J. L. Rapoport, A. M. Addington, S. Frangou, and M. R. C. Psych, "The neurodevelopmental model of schizophrenia: update 2005," Molecular Psychiatry, vol. 10, no. 5, pp. 434-449, 2005.

[38] B. Dean, "Understanding the pathology of schizophrenia: recent advances from the study of the molecular architecture of postmortem CNS tissue," Postgraduate Medical Journal, vol. 78, no. 917, pp. 142-148, 2002.

[39] A. B. Goodman and A. B. Pardee, "Meeting report; 'Molecular neurobiological mechanisms in schizophrenia: seeking a synthesis," Biological Psychiatry, vol. 48, no. 3, pp. 173-183, 2000.

[40] H. Y. Meltzer, "Biochemical studies in schizophrenia," Schizophrenia Bulletin, vol. 2, no. 1, pp. 10-18, 1976.

[41] S. Kapur, "Psychosis as a state of aberrant salience: a framework linking biology, phenomenology, and pharmacology in schizophrenia," The American Journal of Psychiatry, vol. 160, no. 1, pp. 13-23, 2003.

[42] M. Huttunen, "The evolution of the serotonin-dopamine antagonist concept," Journal of Clinical Psychopharmacology, vol. 15, supplement 1, no. 1, pp. 4S-10S, 1995.

[43] B. P. Riley and P. McGuffin, "Linkage and associated studies of schizophrenia," The American Journal of Medical Genetics, vol. 97, pp. 23-44, 2000.

[44] S. I. Deutsch, J. Mastropaolo, B. L. Schwartz, R. B. Rosse, and J. M. Morihisa, "A "glutamatergic hypothesis" of schizophrenia. Rationale for pharmacotherapy with glycine," Clinical Neuropharmacology, vol. 12, no. 1, pp. 1-13, 1989.

[45] C. Abbott and J. Bustillo, "What have we learned from proton magnetic resonance spectroscopy about schizophrenia? A critical update," Current Opinion in Psychiatry, vol. 19, no. 2, pp. 135139, 2006.

[46] L. Tebartz van Elst, G. Valerius, M. Büchert et al., "Increased prefrontal and hippocampal glutamate concentration in schizophrenia: evidence from a magnetic resonance spectroscopy study," Biological Psychiatry, vol. 58, no. 9, pp. 724-730, 2005.

[47] D. A. Lewis and B. Moghaddam, "Cognitive dysfunction in schizophrenia: convergence of $\gamma$-aminobutyric acid and glutamate alterations," Archives of Neurology, vol. 63, no. 10, pp. 13721376, 2006.

[48] E. F. Walker, C. B. Logan, and D. Walder, "Indicators of neurodevelopmental abnormality in schizotypal personality disorder," Psychiatric Annals, vol. 29, no. 3, pp. 132-136, 1999.
[49] E. F. Walker, D. J. Walder, and F. Reynolds, "Developmental changes in cortisol secretion in normal and at-risk youth," Development \& Psychopathology, vol. 13, no. 3, pp. 721-732, 2001.

[50] X. Y. Zhang, D. F. Zhou, L. Y. Cao, G. Y. Wu, and Y. C. Shen, "Cortisol and cytokines in chronic and treatment-resistant patients with schizophrenia: association with psychopathology and response to antipsychotics," Neuropsychopharmacology, vol. 30, no. 8, pp. 1532-1538, 2005.

[51] T. Ohnuma, S. J. Augood, H. Arai, P. J. McKenna, and P. C. Emson, "Measurement of GABAergic parameters in the prefrontal cortex in schizophrenia: focus on GABA content, GABA(A) receptor $\alpha$-1 subunit messenger RNA and human GABA transporter-1 (hGAT-1) messenger RNA expression," Neuroscience, vol. 93, no. 2, pp. 441-448, 1999.

[52] M. M. Huntsman, B. V. Tran, S. G. Potkin, W. E. Bunney Jr., and E. G. Jones, "Altered ratios of alternatively spliced long and short $\gamma 2$ subunit mRNAs of the $\gamma$-amino butyrate type A receptor in prefrontal cortex of schizophrenics," Proceedings of the National Academy of Sciences of the United States of America, vol. 95, no. 25, pp. 15066-15071, 1998.

[53] D. O. Kennedy and E. L. Wightman, "Herbal extracts and phytochemicals: plant secondary metabolites and the enhancement of human brain function," Advances in Nutrition, vol. 2, no. 1, pp. 32-50, 2011.

[54] M. Spinella, The Psychopharmacology of Herbal Medicine: Plant Drugs that Alter the Mind, Brain and Behavior, MIT Press, Cambridge, UK, 2011.

[55] J. Sarris, "Herbal medicines in the treatment of psychiatric disorders: a systematic review," Phytotherapy Research, vol. 21, no. 8, pp. 703-716, 2007.

[56] V. Kumar, "Potential medicinal plants for CNS disorders: an overview," Phytotherapy Research, vol. 20, no. 12, pp. 1023-1035, 2006.

[57] D. S. Avinash, "Herbal medicine and anxiety disorders: an overview," Journal of Medicinal Plants Studies, vol. 1, no. 6, pp. 18-23, 2013.

[58] M. F. Green, Schizophrenia Revealed: From Neurons to Social Interactions, W.W. Norton, New York, NY, USA, 2001.

[59] B. Rosenbaum, K. Valbak, S. Harder et al., "The Danish National Schizophrenia Project: prospective, comparative longitudinal treatment study of first-episode psychosis," British Journal of Psychiatry, vol. 186, pp. 394-399, 2005.

[60] Z. Zhang, "Therapeutic effects of herbal extracts and constituents in animal models of psychiatric disorders," Life Sciences, vol. 75, no. 14, pp. 1659-1699, 2004.

[61] P. Bigoniya and A. C. Rana, "Psychopharmacological profile of hydro-alcoholic extract of Euphorbia neriifolia leaves in mice and rats," Indian Journal of Experimental Biology, vol. 43, no. 10, pp. 859-862, 2005.

[62] M. M. Ghaisas, P. B. Ninave, G. P. Ganu, V. S. Zope, M. B. Tanwar, and A. D. Deshpande, "Effect of Randia dumetorum Lam on clonidine and haloperidol-induced catalepsy in mice," Pharmacologyonline, vol. 2, pp. 42-50, 2008.

[63] S. Kothari, M. Minda, and S. D. Tonpay, "Anxiolytic and antidepressant activities of methanol extract of Aegle marmelos leaves in mice," Indian Journal of Physiology and Pharmacology, vol. 54, no. 4, pp. 318-328, 2010.

[64] K. P. S. Raj and M. R. Patel, "Some medicinal plants of Cambay and its immediate vicinity and their uses in Indian indigenous system of medicine," Indian Drugs, vol. 15, pp. 145-152, 1978. 
[65] J. K. Maheshwari and J. P. Singh, "Plants used in ethnomedicine by the Kols of Allahabad district Uttar Pradesh," Bulletin of Medico-Ethno-Botanical Reserch, vol. 5, pp. 105-121, 1984.

[66] M. Rahmatullah, A. Hasan, and W. Parvin, "Medicinal plants an formulations used by the sore clan of the Santal tribe in Rajshahi District, Bangladesh for treatment of various ailemnts," African Journal of Traditional, Complementary, and Alternative Medicines, vol. 9, no. 3, pp. 350-359, 2012.

[67] M. Rahmatullah, Md. A. H. Mollik, A. T. M. A. Azam et al., "Ethnobotanical survey of the Santal tribe residing in Thakurgaon District, Bangladesh," American-Eurasian Journal of Sustainable Agriculture, vol. 3, no. 4, pp. 889-898, 2009.

[68] M. H. Boskabady, S. Kiani, and B. Haghiri, "Relaxant effects of Ocimum basilicum on guinea pig tracheal chains and its possible mechanism(s)," DARU, vol. 13, no. 1, pp. 28-33, 2005.

[69] M. Md. Rashid, F. B. Rafique, N. Debnath et al., "Medicinal plants and formulations of a community of the Tonchongya tribe in Bandarban district of Bangladesh," The AmericanEurasian Journal of Sustainable Agriculture, vol. 6, no. 4, pp. 292-298, 2012.

[70] N. L. Soh and G. Walter, "Traditional and alternative medicine treatments in child and adolescent mental health," in IACAPAP $e$-Textbook of Child and Adolescent Mental Health, J. M. Rey, Ed., International Association for Child and Adolescent Psychiatry and Allied Professions, Geneva, Switzerland, 2012.

[71] V. Agarwal, A. Abhijnhan, and P. Raviraj, "Ayurvedic medicine for schizophrenia," Cochrane Database of Systematic Reviews, vol. 3, Article ID CD006867, 2010.

[72] L. B. Borse, A. K. Muthu, A. Thangatripathi, and S. L. Borse, "Antidopaminergic activity of vitex negundo (linn) roots," Asian Journal of Chemistry, vol. 24, no. 7, pp. 3171-3173, 2012.

[73] R. S. Adnaik, P. T. Pai, V. D. Sapakal, N. S. Naikwade, and C. S. Magdum, "Anxiolytic activity of Vitex negundo linn. in experimental models of anxiety in mice," International Journal of Green Pharmacy, vol. 3, no. 3, pp. 243-247, 2009.

[74] F. M. Leweke, D. Piomelli, F. Pahlisch et al., "Cannabidiol enhances anandamide signaling and alleviates psychotic symptoms of schizophrenia," Translational Psychiatry, vol. 2, article e94, 2012.

[75] S. Deiana, "Medical use of cannabis. Cannabidiol: a new light for schizophrenia?" Drug Testing and Analysis, vol. 5, no. 1, pp. 46-51, 2013.

[76] A. W. Zuardi, J. A. Crippa, J. E. Hallak et al., "A critical review of the antipsychotic effects of cannabidiol: 30 years of a translational investigation," Current Pharmaceutical Design, vol. 18, no. 32, pp. 5131-5140, 2012.

[77] P. Vijayapandi, N. Megala, and M. Zahurin, "Antipsychoticlike activity of noni (Morinda citrifolia Linn.) in mice," BMC Complementary and Alternative Medicine, vol. 12, article 186, 2012.

[78] M. N. K. Azam, M. A. Mannan, and M. N. Ahmed, "Medicinal plants used by traditional medical practitioners of Barendra and Shamatat (Rajshahi Khulna division) region in Bangladesh for treatment of cardiovascular disorders," Journal of Medicinal Plants Studies, vol. 2, no. 2, pp. 9-14, 2014.

[79] M. Rahmatullah, S. Hossain, A. Khatun, S. Seraj, and R. Jahan, "Medicinal plants used by various tribes of Bangladesh for treatment of Malaria," Malaria Research and Treatment, vol. 2012, Article ID 371798, 5 pages, 2012.

[80] M. A. H. Mollik, "A preliminary study on the efficacy of medicinal plants from the Lawacherra Rain Forest used for all forms of brain disorders," Alzheimer's \& Dementia, vol. 6, supplement 4, p. S44, 2010.

[81] M. N. Ahmed, M. N. K. Azam, U. S. Zohora, and M. N. Hasan, "Use of medicinal plants against snake venom to treat snake bite by folk medicinal practitioners in Barandra and Shamatat region of Bangladesh," in Proceedings of the International Conference Updates on Natural Products in Medicine and Healthcare Systems, Khulna, Bangladesh, July 2013.

[82] M. N. Hasan, M. N. Ahmed, M. Z. A. Bhuiyan, M. M. Rahman, M. N. K. Azam, and M. Rahmatullah, "Medicinal plants used in treatment of tumors: results from a survey of folk medicinal practitioners," in Proceedings of the International Conference on Green Chemistry for Sustainable Development, Jessore, Bangladesh, July 2012.

[83] M. Rahmatullah, R. Jahan, A. K. Azad et al., "A randomized survey of medicinal plants used by folk medicinal practitioners in six districts of Bangladesh to treat rheumatoid arthritis," Advances in Natural and Applied Sciences, vol. 4, no. 2, pp. 124127, 2010.

[84] M. Rahmatullah, M. N. K. Azam, Z. Khatun et al., "Medicinal plants used for treatment of diabetes by the Marakh sect of the Garo tribe living in Mymensingh district, Bangladesh," The African Journal of Traditional, Complementary and Alternative Medicines, vol. 9, no. 3, pp. 380-385, 2012.

[85] M. A. H. Mollik, "Beideyes in Kurigram district of Bangladesh: their knowledge of common mental health problems and possible role in primary health care," Alzheimers Dementia, vol. 6, no. 4, article S337, 2006. 


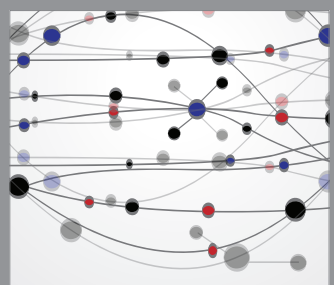

The Scientific World Journal
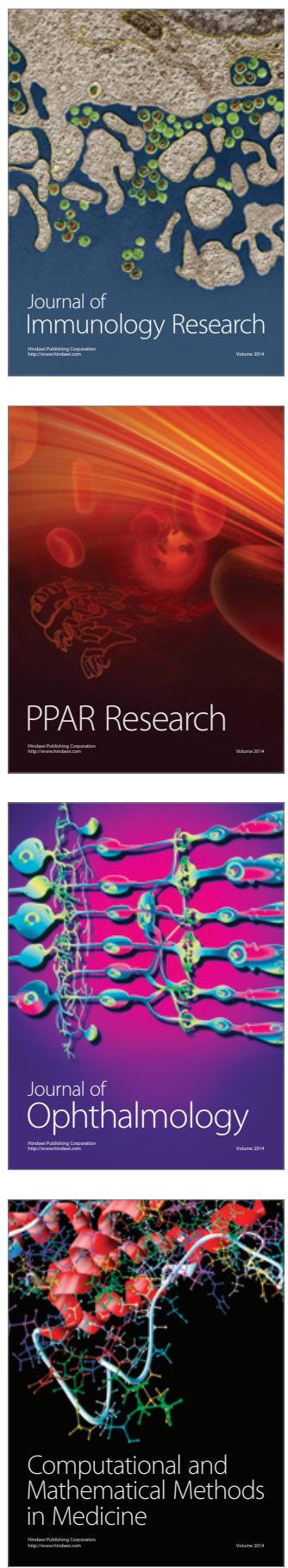

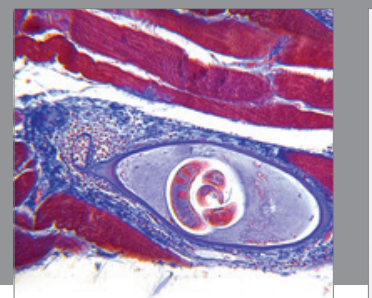

Gastroenterology

Research and Practice
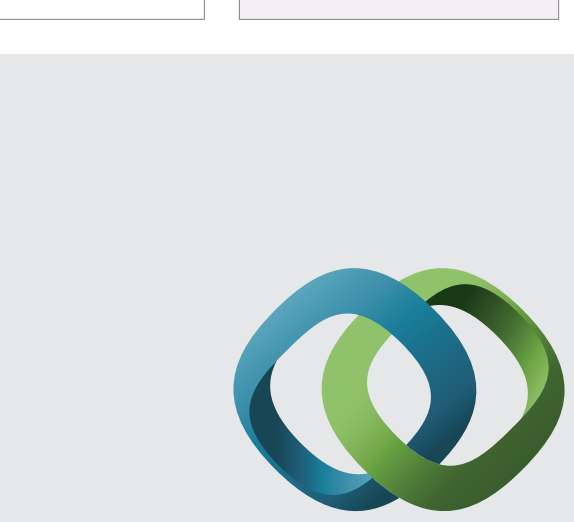

\section{Hindawi}

Submit your manuscripts at

http://www.hindawi.com
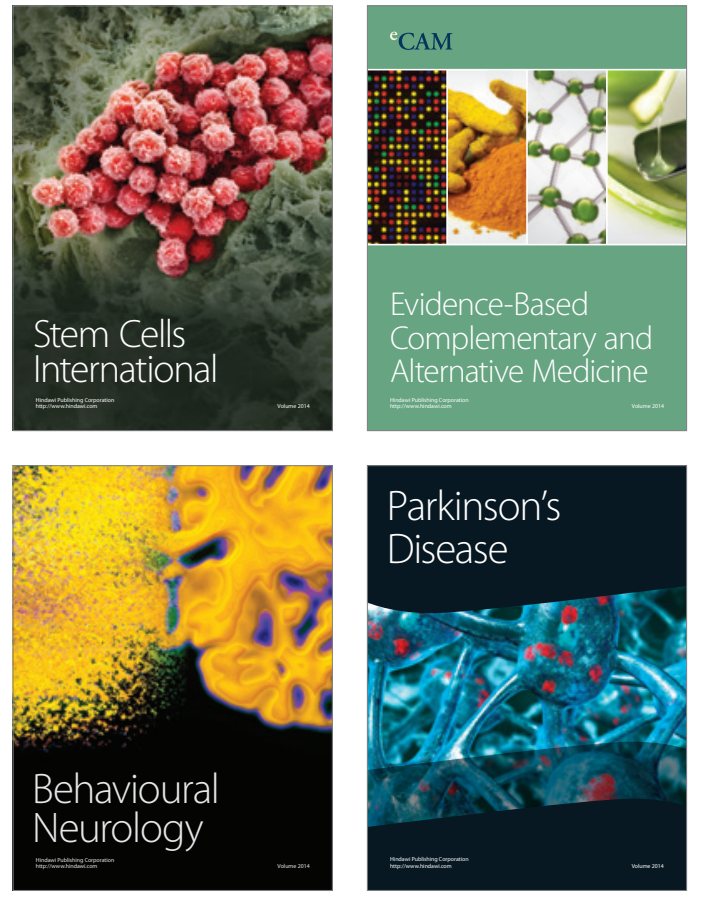
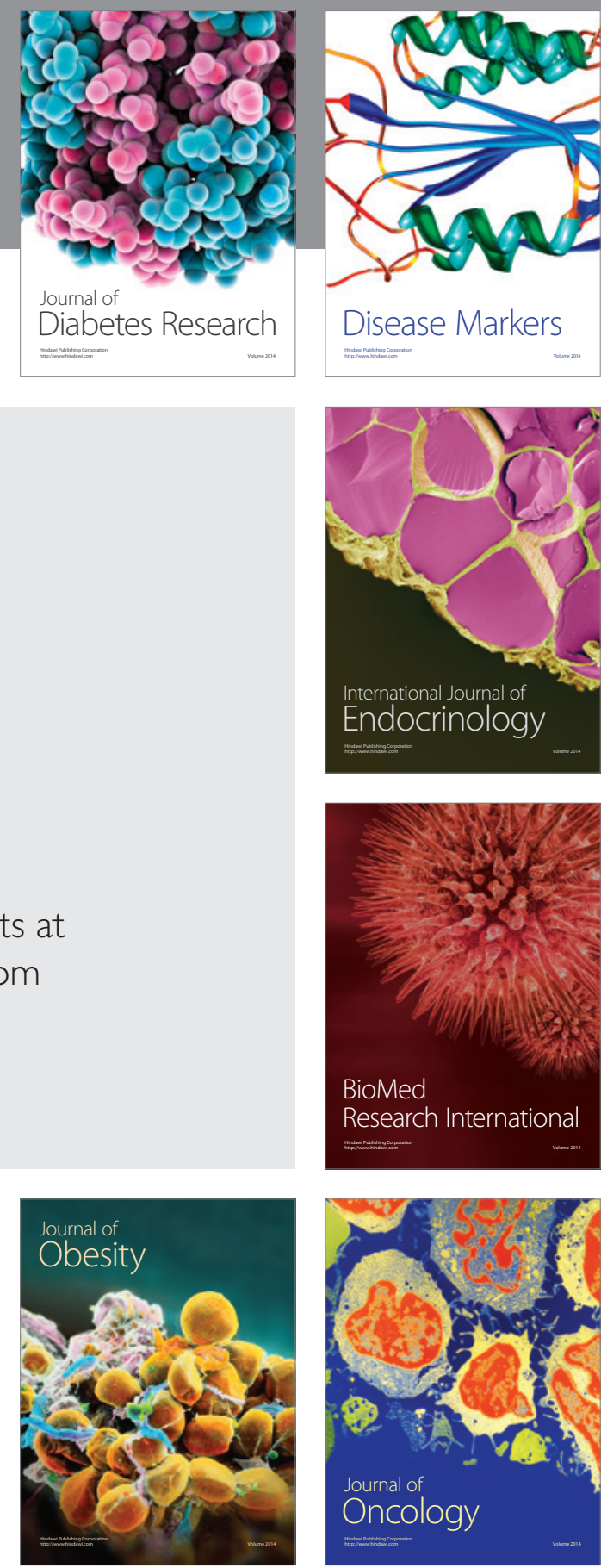

Disease Markers
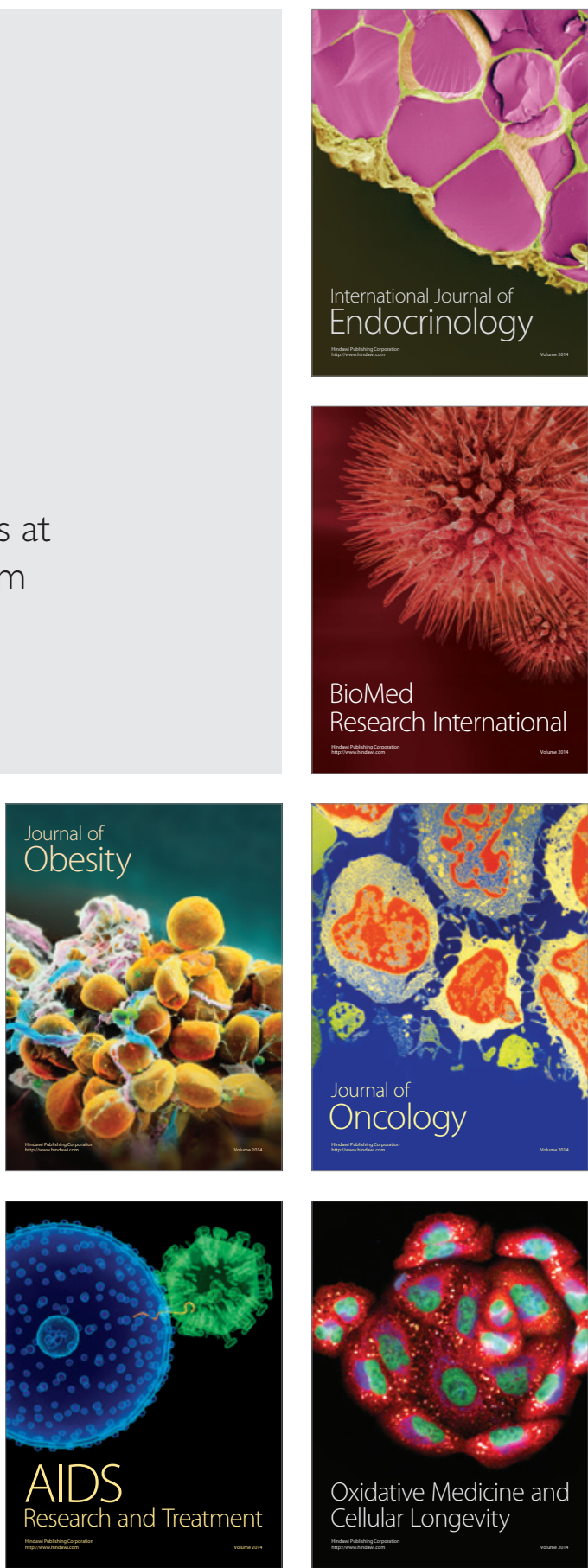